\title{
Floral vasculature and trichomes of common Indian Scrophulariaceae
}

\author{
P. C. DATTA and ARATI DEB \\ Department of Botany, University of Calcutta, \\ Calcutta-700019, India \\ (Received: September 21, 1974)
}

\begin{abstract}
The floral anatomy of 24 species of Scrophulariaceae was studied. The results show that although, clear anatomical bases to differentiate taxa are absent, the Pennell classification of subfamilies is strongly supported.
\end{abstract}

\section{INTRODUCTION}

B enth a m and Hooker (1873) classified the family Scrophulariaceae into three series, Pseudosolaneae, Antirrhinideae and Rhinanthideae. W e t t s t e i n's classification (1897) retained the same major groups (subfamilies Pseudosolaneae, Antirrhinoideae and Rhinanthoideae). But P e nn ell (1935) drops the group Pseudosolaneae. The outstanding differences between these three exhaustive treatments are in the positions and delimitations of tribes under the subfamilies. Major groups in these classifications, given below, provide idea of the basic differences.

Bentham \& Hooker Wettstein (1873)

A. Pseudosolaneae
Leucophylleae
Aptosimeae
Verbasceae
B. Antirrhinideae

Calceolarieae

H. Hemimerideae

Antirrhineae

Chelomeae

Manuleieae

Gratioleae

C. Rhinanthideae

Digitaleae

Gerardieae

Euphrasieae
(1897)

\begin{tabular}{l} 
A. Pseudosolaneae \\
\hline Verbasceae \\
Aptosimeae \\
B. Antirrhinoideae \\
\hline Hemimerideae \\
Calceolareae \\
Antirrhineae \\
Cheloneae \\
Manuleae \\
Gratioleae \\
Selagineae \\
C. Rhinanthoideae \\
\hline Digitaleae \\
Gerardieae \\
Rhinantheae
\end{tabular}

P e n n e ll

(1935)

A. Antirrhinoideae

Gratioleae

Verbasceae

Leucophylleae

Cheloneae

Collinsieae

Antirrhineae

B. Rhinanthoideae

Digitaleae

Veroniceae

Buchnereae

Euphrasieae 
Hence is the present attempt to examine the conitroversies on the basis of vascular traces of flowers, utility of which has been emphasised by different authors (F i s her, 1928; B a n croft, 1935; M a thews, 1941; J u s t, 1952; P u ri, 1951; E a m e s, 1953, 1961).

Floral anatomy of discrete genera of the family has been studied (Sopubia and Vandellia by Krishn a I y en g r, 1937, 1940a, b; Scoparia by $\mathrm{R}$ agh avan and Srinivasan, 1941; B a copa by Sì fee u l$1 \mathrm{a}$ and Govinda, 1950; Veronica by S a u d e r s, 1934; Angelonia and Striga by Srinivasan (V. K.), 1940; Srinivasan (A. R.), 1964; $\mathrm{H}$ a r t l, 1956, etc.). The present investigation is for comparison between different genera and species.

\section{MATERIAL AND METHODS}

24 species mentioned below (arranged according to W etts tein, 1897) are included in the present study. Plants were mostly collected from Calcutta and its suburbs and some from the herbarium of Calcutta University and from Botanical Survey of India (Western and Eeastern Circles). All specimens were compared with those of the Herbaria of Calcutita University and Botanical Survey of India at Shibpur (Calcutta) for identification. Nomenclatures were corrected by consulting $\mathrm{R}$ a i zada (1958) and P e n n e 11 (1935).

Flower buds, two to three days before anthesis, were fixed in formalin-propionic acid-alcohol ( $\mathrm{J}$ o h a n s e n, 1940), washed, dehydrated and

\section{Species}

A. Sub-family Pseudosolaneae

I. Tribe Verbasceae

1) Verbascum virgatum Stokes

B. Sub-family Antirrhinoideae

I. Tribe Hemimerideae

1) Angelonia grandiflora C. Morr.

II. Tribe Calceolarieae

1) Calceolaria mexicana Benth.

III. Tribe Antirrhineae

1) Linaria bipartita Willd.

2) Antirrhinum majus L.

IV. Tribe Cheloneae

1) Russelia equisetiformis Schlecht. Cham. = Russelia juncea Zucc.

2) Wightia speciosissima (D. Don) Merr.

$=$ Wightia gigantea Wall.

6 V. Tribe Manuleae

1) Sutera glandulosa Roth.
Collector, source

Locality

Agharkar, S.N.; Calcutta

C.U.

Scrop 18(10); C.U. Unknow

Dep Scrop 2; C.U. Darjeelin (W. Bengal)

Banerjee, S.N.; Calcutta

C.U.

Deb Scorp 3; C.U. Calcutta

Deb Scrop 4; C.U. Calcutta

Deb Scorp 5; C.U. Punjab

Deb Scorp 6; C.U. Poona

(B.S.I.) 


\section{Species \\ Collector, source \\ Locality}

VI. Tribz Gratesleae

1) Mazus japonicus (Thumb.) Kuntze

Deb. Scrop 7; C.U. Calcutta = Mazus rugosus Lour.

2) Lindenbergia indica (L.) Kuntze $=$ Lindenbergia urticaefolia Lehm.

3) Brama monnieri (L.) Pennell = Bacopa monnieri (L.) Wettst. = Herpestis monniera (L.) H.B. \& K.

4) Pagesia dianthera (Swantz) Pennell =Herpestis chamaedroides H.B. \& K.

5) Torentia fournieri Linden

6) Torenia vagans Roxb.

Dep Scrop 9; C.U. Garia (W. Bengal)

7) Lindernia crustacea (L.) Mueller $=$ Vandellia crustacea $($ L.) Benth.

8) Lindernia ciliata (Colsm.) Pennell = Bonnaya brachiata Link \& Otto

9) Lindernia multiflora (Roxb.) Mukherjee $=$ Vandellia multiflora D. Don. Gen.

Deb Scrop 10; C.U. Garia (W. Bengal)

Deb Scrop 11; C.U. Ballygunje (Calcutta)

Deb Scrop 12; C.U. Ballygunje (Calcutta)

Deb Scrop 13; C.U. Ballygunje (Calcutta)

Deb Scrop 14; C.U. Ballygunje (Calcutta)

Deb Scrop 15; C.U. Ballygunje (Calcutta)

C. Sub-family Rhinanthoideae

I. Tribe Digitaleae

1) Scoparia dulcis L.

Deb Scrop 16; C.U. Ballygunj

2) Veronica himalensis D. Don. Prod.

Agharkar, S.N.;

(Calcutta)

C.U.

3) Digitalis purpurea L.

Deb Scorp 17; C.U. Darjeelin

(W. Bengsl)

II. Tribe Gerardieae
1) Alectra arvensis (Benth.) Merrill
Ghosh, S.N.; C.U.
Assam Hill =Alectra indica Benth.
2) Centranthera nepalensis D. Don $=$ Centanthera hispida $\mathrm{Hk}$. f. non $\mathrm{R} . \mathrm{Br}$
Cambell 9867; C.U. Manbhum Khan, S.N.; C.U. Mysore (W. Bengal)
3) Striga gesneroides (Willd) Vatke $=$ Striga oronbranchoides $(\mathrm{R} . \mathrm{Br}$.) Benth.

III. Tribe Rhinantheae

1) Pedicularis furfuracea Wall. Cat.
Agharkar, S.N.;
Cholan
C.U.

embedded in paraffin in usual procedures. Paraffin blocks were microtomed at $15 \mu$ thickness, and serial sections (T. S. \& L. S.) were dewaxed, stained with crystal violet, dehydrated and mounted in Canada balsam. Dry old specimens were swelled by boiling in water, cleared in equal proportion of ammonium hydroxide and hydrogen peroxide (conc.) for 24 hours, washed in running water for an hour and then treated as a fresh material.

The specimens have been cited according to procedure recommended by $\mathrm{S}$ t e rn and $\mathrm{Ch}$ a $\mathrm{m}$ ber (1960). 


\section{OBSERVATION}

The family generally possesses centripetal inflorescence (centrifugal in Cheloneae), sometimes compound or with solitary flowers. Bracteoles are generally two. Ebracteolate genera are Angelonia, Linaria, Antirrhinum, Sutera, Mazus, Lindenbergia, Torenia, Lindernia, Scoparia, Veronica, Pedicularis, etc.

Sepals are always connate, generally numbering five. Calyx is generally 5-partite or deeply 5-lobed (campanulate in Mazus, Lindenbergia, Alectra; campanulate and 3-4 lobed in Wightia; 4-partite in Scoparia and Calceolaria, 2-lipped in Torenia), imbricate or quincuncial. In the species having five sepals, the position of the external sepal lobe or lobes is anterior in Verbascum, Angelonia, Antirrhinum, Russelia, Lindenbergia, Lindernia, Centranthera, while it is posterior in Linaria, Wightia, Mazus, Pagesia, Brama, Horenia, Veronica, Digitalis, Alectra and Striga. Corolla is generally tubular, excepting Angelonia. It is rotate in Verbas. cum, Scoparia and Veronica, campanulate in Alectra and Brama, and declined in Digitalis. Tubes are generally slenderly cylindrical, spurred ir Linaria, saccate in Antirrhinum, incurved in Russelia and Centranthera, narrow at base having nectar glands in Pedicularis, short ir. Mazus. Stamens are generally four in number, included and didynamous The number is five in Verbascum, two in Veronica (posterio-lateral pair, and Calceolaria (lateral pair). Filaments are distinctly short in Angelonia, exerted in Wightia and Veronica. Stigma is minute (Linaria, Russelia, Calceolaria), capitate (Verbascum, Lindenbergia), subcapitate (Veronica), 2-lobed (Antirrhinum, Sutera, Brama, etc.), 2-lamellate (Mazus, Torenia, Lindernia, etc.), distinct (Pedicularis, Digitalis, and many species of Grateoleae), truncated (Scoparia), linguiformis (Centranthera, Alectra), entire (Striga, Pagesia), or dilated (Wightia).

Although the vascular anatomy of flowers of Scrophulariaceae follows a common plan, distinguishable characters are also available in many species and genera. Sepals are supplied by sepal-midrib traces and sepal-lateral commisural strands. A sepal-midrib trace generally forms a cord with a stamen trace. A petal-midrib trace forms a cord with a sepal-lateral commisural strand. The number of stamen traces varies from five to four, of which one or two are often vestigial. Number of disc traces, if present, is variable. Minor variations are noticed in the ovarian traces.

\section{Receptacle}

The receptacular vascular bundles generally form a continuous cylinder, circular in transection, with external phloem and internal endarch xylem. In Calceolaria mexicana, six to seven discrete bundles form a cir- 

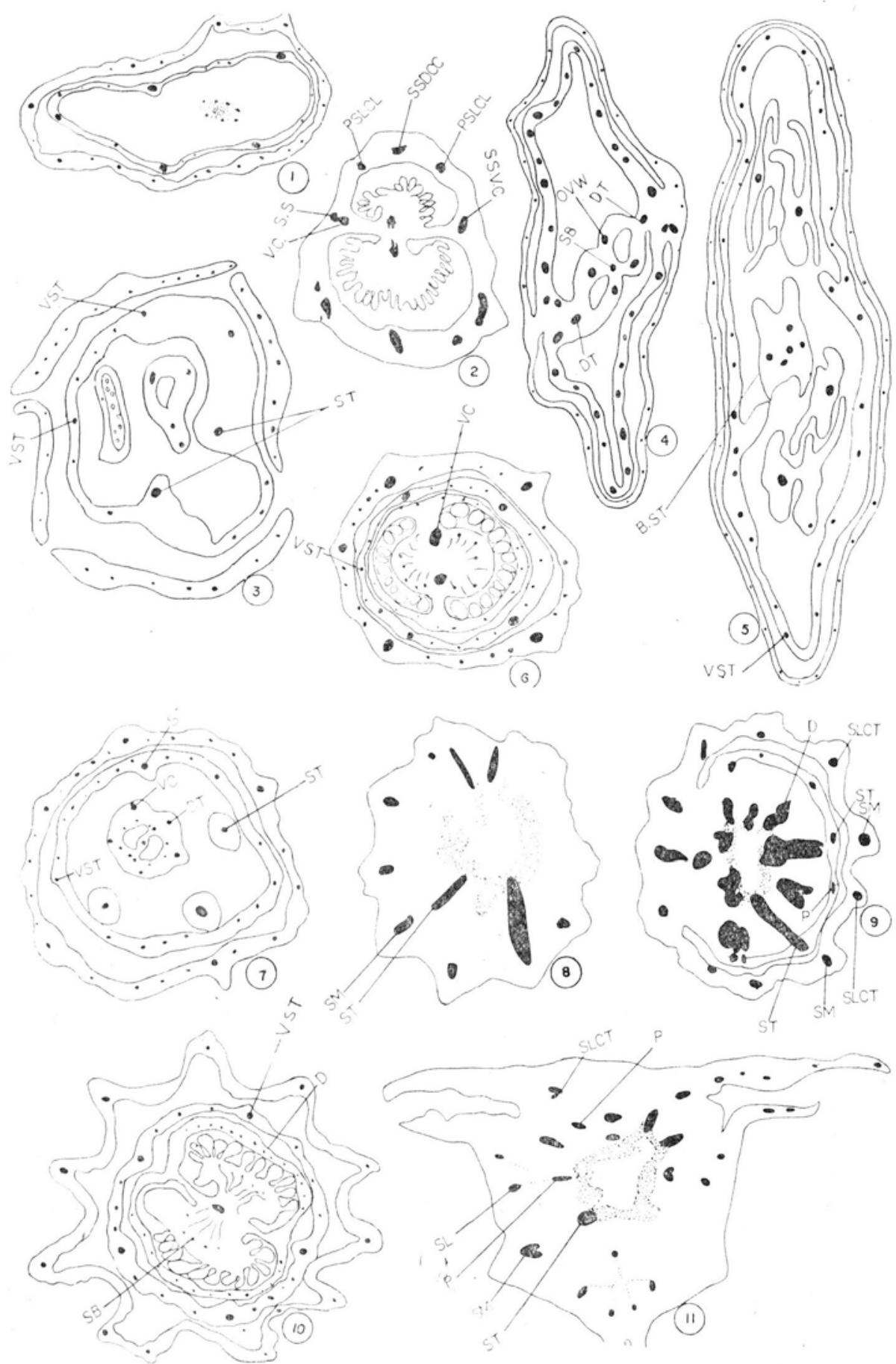

Figs. 1-11. Camera lucida drawings of transections of flower buds showing vascular traces. 1. Verbascum virgatum; 2 \& 3. Calceolaria mexicana showing two vestigial stamen traces; 4 \& 5. Linaria bipartita showing one vestigial stamen trace; $6 . \& 7$. Majus japonicus; 8-10. Lindenbergia indica; 11 . Pagesia dianthera. (B. S. T. - bent end of store; $D$ - disc trace; $D T$ - dorsal trace of carpel; OV. W. - ovary wall trace; $P$ - petal midrib; $P S L C L$ - petal + sepal lateral + carpel lateral cord; $S B$ - septal bundle; $S L$ - sepal lateral trace; $S L C T$ - sepal lateral commisural strand; $S M$ - sepal midrib; $S S$ - sepal stamen cord; $S S D C C$ - sepal + stamen + dorsal carpel trace cord; SSVC - sepal + stamen + ventral carpel trace cord; $S T$ - stamen tracc; VC - ventral commisural trace of carpels; VST - vestigia] 


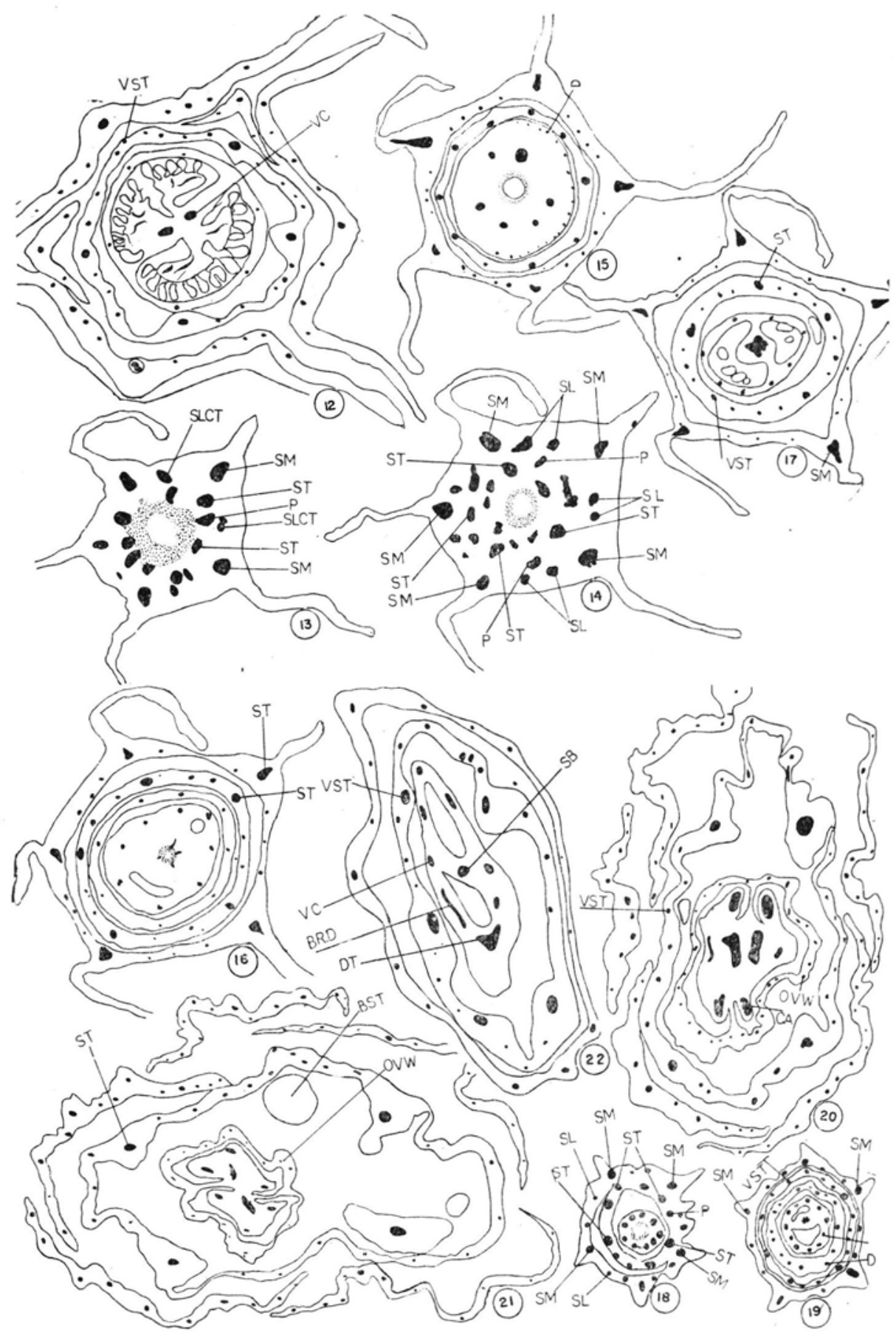

Figs. 12-22. Camera lucida drawings of transections of flower buds showing vascular traces. 12. Pagesia dianthera, 13-17. Torenia fournieri, 18-19. T. vagans; 20-21. Digitalis purpurea; 22. Pedicularis furfuracea. (CA - central arches, BR. D. brarching of dorsal trace of carpel. Other indications as in the previous plate) 


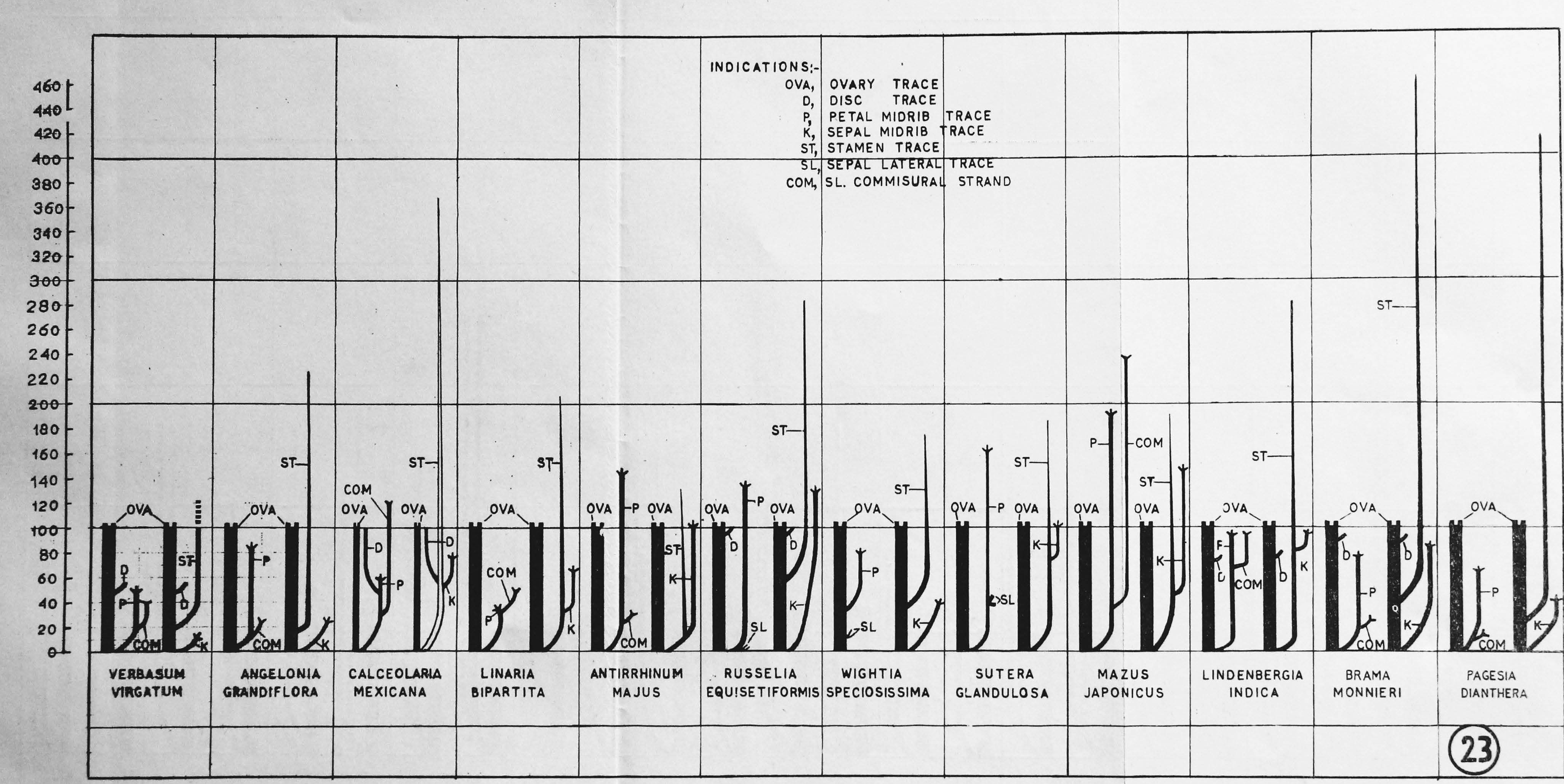

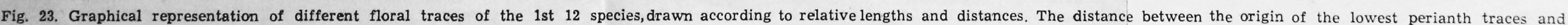

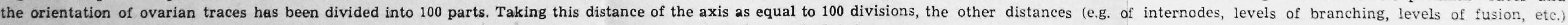
have been calculated 


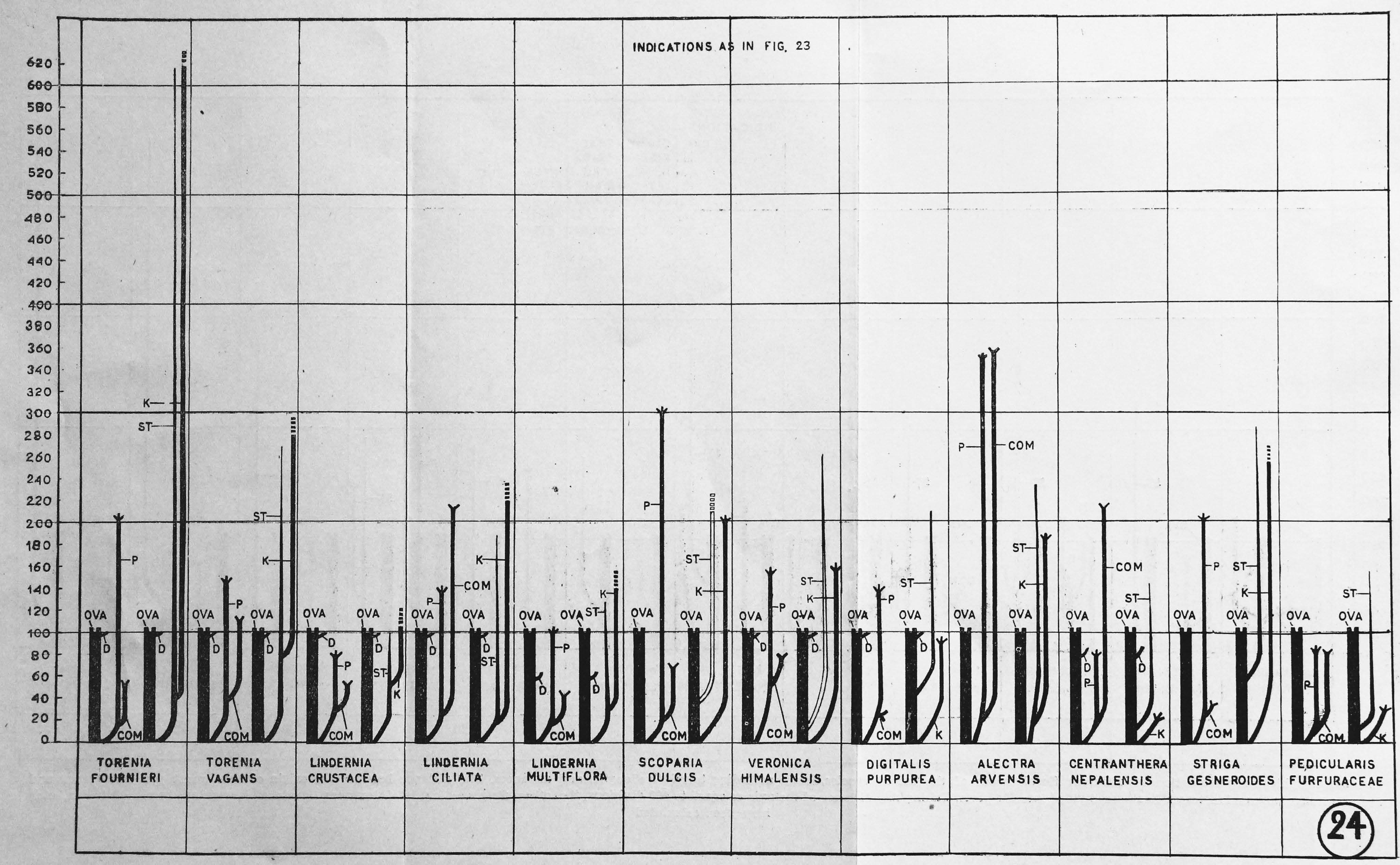

Fig. 24. Graphic representation of different floral traces of the next lot of 12 species, drawn according to relative lengths and distances, as in Fig. 23 
cular ring. In Mazus japonicus the cylinder is divided into two arches below. In Lindernia multiflora, the 5-angled pedicel contains four bundles which gradually coalesce into a cylinder, circular in transection.

\section{Bracteoles}

Each member receives a single trace. In Verbascum virgatum, the two bracteole traces originate fused with two sepal-midrib traces and diverge into the bracteolar protrusions. In Brama monnieri two traces come out from two corners of a triangular and continuous vascular cylinder of a triangular pedicel and supply the two bracteoles. In Alectra arvensis the single bracteolar trace branches immediately into four to five bundles. They arise markedly below the perianth of Centranthera nepalensis and branch immediately. In Striga gesneroides, they arise slightly below the perianth.

Calyx

(a) Species without fusion of sepal-main and stamen traces:

The connate calyx (in most of the genera) or almost free sepals (in Angelonia grandiflora) are supplied altogether by 10 bundles, five sepal-main (or sepal-midrib) bundles and five sepal (commisural) + petal cords alternating them. These cords (absent in Wightia speciosissima) bifurcate radially into the outer commisural strand and the inner petalmidrib bundie. The commisural strands bifurcate tangentially to supply the adjacent sepals as sepal-laterals. This condition is common in Verbascum virgatum (Verbasceae), Angelonia grandiflora (Hemimerideae), Russelia equisetiformia and Wightia speciosissima (Cheloneae), Brama monnieri and Pagesia dianthera (Gratioleae), and almost all members of Rhinanthoideae (Scoparia dulcis, Veronica himalensis, Digitalis purpurea, Centranthera nepalensis, Striga gesneroides and Pedicularis furfuracea (Figs. 22, 23 \& 24).

(b) Species with sepal-main + stamen cord:

In most of the remaining species examined (Linaria bipartita and Antirrhinum majus of Antirrhineae; Sutera glandulosa of Manuleae; Mazus japonicus, Lindenbergia indica, Torenia fournieri, T. vagans, Lindernia crustacea, L. ciliata and L. multiflora of Grateoleae; Alectra arvensis of Gerardieae), sepal-midrib bundles are fused below with five stamen bundles (sepal-midrib + stamen cord). 
An extreme type of adhesion is noticed in Calceolaria mexicana (Calceclarieae) where eight cords (two formed by adhesion bundles of sepal-main and stamen with the commisural bundles of ventral traces of a carpel, two formed by adhesion of bundles of sepal-main and stamen with dorsal carpellary traces and four formed by petal-midrib with sepal-lateral commisural strand and carpel-lateral traces) arise first. They divide to produce inner eight carpellary bundles and outer four sepal-main + stamen cords and four sepal-lateral + petal-midrib cords (Figs. 2, 8, 9, 23 \& 24).

The number of such basal bundles varies according to species. It is 10 in Verbascum, Angelonia, Linaria, Antirrhinum, Russelia, Wightia, Sutera, Brama, Pagesia, Torenia, Lindernia, Digitalis, Alectra, Centranthera, Striga and Pedicularis; eight in Calceolaria, Scoparia and Veronica. The proportional lengths of the adhesion cords and sepal-lateral commisural strands have been given in Figs. $23 \& 24$.

The level of branching of sepal-midrib traces varies in different species. It is highest in Scoparia dulcis and lowest in Verbascum virgatum (Figs. 23 \& 24) while in the different species of Torenia and Lindernia and in Striga gesneroides, the midrib bundle is unbranched (Fig. 24).

The height of the sepal-lateral commisural strand also differs, highest in Alectra arvensis, lowest in Wightia speciosissima, absent in Russelia equisetiformis, Sutera glandulosa and Digitalis purpurea (Figs. 23 \& 24).

\section{Corolla}

Petals and stamens form a sincle tube. A petal is supplied by a single trace (petal-midrib trace) which generally arise fused with the sepal-lateral commisural strand. The height of such a cord varies according 10 species, highest in Lindenbergia indica and lowest in Pagesia dianthera, absent in Wightia speciosissima (Figs. 23 \& 24). In Calceolaria mexicana the petal-midrib bundles form cords with sepal-lateral commisural strands and carpel-lateral bundles (Fig. 2). The number of petal-midrib traces (or their adhesion cords) varies according to species, five in Verbascum virgatum (Fig. 1), Angelonia grandiflora, Linaria bipartita, Antirrhinum majus, Russelia equisetiformis, Wightia speciosissima, Sutera glandulosa, Brama monniéri, Pagesia dianthera, Torenia species (Figs. 15 \& 18), Lindernia species, Digitalis purpurea, Alectra arvensis, Centranthera nepalensis, Striga gesneroides and Pedicularis furfuracea, while four in Calceolaria mexicana, Scoparia dulcis and Veronica himalensis. The level of branching of petal traces varies according to species, highest in Alectra arvensis and lowest in Linaria bipartita (Figs. 23 \& 24). The lowest lateral branches of each petal midrib trace act as lateral traces. The midrib traces branch out further in the lobes. 


\section{Androecium}

The corolla tube receives traces for stamens, alternating with the petal-midrib traces. Stamen traces arise independent of sepal traces in Verbascum virgatum, Angelonia grandiflora, Russelia equisetiformis, Wightia speciosissima, Brama monnieri, Pagesia dianthera, Scoparia dulcis, Veronica himalensis, Digitalis purpurea, Centranthera nepalensis, Striga gesneroides and Pedicularis furfuracea. In these species, the distance between traces for sepals and stamens, relative to the length of axis, is longest in Russelia equisetiformis and shortest in Centranthera nepalensis. In Calceolaria mexicana the stamen traces form fusion bundles (cords) with sepal and carpel traces. In the remaining species, the stamen traces form cords with the sepal-midrib traces. The relative length of the cord is highest in Torenia vagans and Sutera glandulosa and lowest in Antirrhinum majus (Figs. 23 \& 24). One vestigial stamen trace is common in the family (absent in Verbascum virgatum having five fertile stamens and in Scoparia dulcis having four fertile stamens). Two vestigial stamens are found in Calceolaria mexicana and Veronica himalensis. Lengths of vestigial stamen traces (relative to axes) vary according to species, longest being in Lindernia crustacea (Figs. 23 \& 24). The position of the vestigial stamen trace, where present, is always against the external calyx-lobe, regardless of anterior or posterior position of the latter.

On the basis of stamen traces, the species may be classified into the following four categories:

(a) Species with five fertile stamens:

Verbascum virgatum has five functional stamens (as reported by F e r n a ld, 1950) and five distinct stamen traces having no adhesion with traces of other whorls. Each bold stamen trace bifurcates, one branch remaining in the corolla-stamen tube and discontinuing immediately and the other branch supplying the sessile connectives. The latter divides again in the connective to supply the two anther-lobes (Fig. 1).

(b) Species with four fertile stamens and one staminode:

Species including Angelonia grandiflora, Antirrhinum majus, Wightia speciosissima, Russelia equisetiformis, Digitalis purpurea (Fig. 20), Alectra arvensis, though have four functional stamens, possess five traces for stamens. The fate of the trace for staminode differs according to species. In Russelia equisetiformis, it is quite long continuing upto the level of anther base of fertile stamens. In Wightia speciosissima and Angelonia 
grandiflora, it is comparatively short, and discontinue much below the level of separation of normal filaments from the corolla tube. In Alectra arvensis it continues upto the level of anther lobes and Antirrhinum majus it is extremely short. A r ber (1932) states that in Digitalis purpurea the fifth stamen is represented by a small ephemeral protrusion without a vascular strand. The present study reveals a clear vestigial strand. The present study reveals a clear vestigial stamen trace in the corolla tube but not in the protrusion. In Angelonia grandiflora, Wightia speciosissima and Russelia equisetiformis it is distinct from the sepal midrib trace, while in Antirrhinum majus and Alectra arvensis, it forms an adhesion bundle with the sepal-midrib trace. In all these species the staminode trace gradually becomes narrow in the staminode, and does not produce any branch.

(c) Species with four fertile stamens without clear staminode:

Species, including Linaria bipartita (Fig. 5), Sutera glandulosa, Mazus japonicus (Figs. 6 \& 7), Lindenbergia indica (Fig. 10), Brama monnieri, Pagesia dianthera (Fig. 12), Torenia fournieri (Fig. 17), T. vagans (Fig 19), Lindernia crustacea, L. ciliata, L. multiflora, Centranthera nepalensis, Striga gesneroides, Pedicularis furfuracea (Fig. 22), have four functional stamens, but five stamen traces. The fifth (vestigial) stamen trace becomes narrow at the end and discontinues. In Scoparia dulcis, the fifth trace is absent. Sepal + stamen cord is absent in Brama monnieri, Pagesia dianthera, Centranthera nepalensis, Striga gesneroides, Pedicularis furfuracea and Scoparia dulcis. In other species of this group the stamen trace arises jointly with the sepal midrib trace. Relative lengths of the sepal stamen cords and vestigial stamen traces (where present) varies according to species (Figs. 23 \& 24).

(d) Species with two functional stamens:

Veronica himalensis and Calceolaria mexicana are the two species where only two fertile stamens are observed. In the former, a posterio-lateral pair and in the latter (Fig. 3), the lateral pair are developed into normal stamens. In Calceolaria mexicana, four stamen traces remain fused below with sepal-midrib traces, of which two remain fused with the dorsal carpellary traces and two with the two ventral commisural traces of carpels. The carpellary traces are separated above from the sepal-stamen cords. In Veronica the four stamen traces originate free from adhesion. In both the species two or the four stamen traces are vestigial. 


\section{Disc}

Disc is present in Verbascum virgatum, Russelia equisetiformis, Lindenbergia indica, Brama monnieri, Pagesia dianthera, Torenia fournieri, T. vagans, Lindernia crustacea, L. ciliata, L. multiflora, Veronica himalensis, Digitalis purpurea. It is absent in other species studied here. The number of disc traces varies according to species. It is $10-12$ in Verbascum virgatum, indefinite in Russelia equisetiformis, 8-10 in Lindenbergia indica, 4-5 in Brama monnieri, \pm 16 in Pagesia dianthera, 12-16 in Torenia species, 12-16 in Lindernia crustacea and L. ciliata, 8 in L. multiflora; 3-4 in Digitalis purpurea, 4-5 in Veronica himalensis. In Verbascum virgatum and Russelia equisetiformis, the disc traces originate directly from the stele, below the organization of carpellary traces. In Lindernia species, Brama monnieri, Pagesia dianthera, Torenia species and Lindenbergia indica, the traces for disc and carpel originate at the same level from the stele. Traces for disc and ovary arise fused in Veronica himalensis and Digitalis purpurea. Height of disc traces, relative to length of axis, varies according to species (Figs. 23 \& 24).

\section{Gynaecium}

Generally, after departure of the staminal traces, vascular tissue of the axial stele organizes into four broad bundles (two dorsal bundle-complexes, here mentioned as dorsal trace and two ventral complexes formed by fusion of two ventral bundles of adjacent carpels, placento-parietal bundles of $\mathrm{R}$ a $\mathrm{o}, 1953$, but here mentioned as commisural ventral strands) and four narow lateral bundles.

The patterns of vascular orientation encountered in the present study are of the following categories:

1. Species with eight basal traces: two commisural ventral strands enter the septum producing minor peripheral branches

In Mazus japonicus and Lindenbergia indica of Grateoleae, eight parietal bundles (two commisural ventral, two dorsal and four lateral) are found. The amphicribral commisural ventral strands are typical placento-parietal bundles, producing peripheral branches supplying ovary wail and enter the septum to supply the ovules. The number of bundles in the middle part of the ovary wall is \pm 10 in M. japonicus (Fig. 7) and 28-30 in L. indica. 
ovary wall. This central cylinder divides into two arches towards the placentae of two chambers. The hollow style is supplied by two dorsal traces.

Both Veronica himalensis and Scoparia dulcis, highly reduced in other character's, have a single branch produced from one commisural ventral strand. Both the species have eight peripheral bundles at the base. $S$. dulcis has a hollow style supplied by two dorsal traces, which fuse in the upper solid part. Henslow (1891) also mentions of a single trace entering the septum of $V$. spicata.

Under Gerardieae, Alectra arvensis, Centranthera nepalensis and Striga gesneroides have a similar plan of eight peripheral bundles and a single branch supplying the septum. In A. arvensis the wall bundles become branched into \pm 16 bundles, in $C$. nepalensis $10-12$ bundles and in $S$. gesneroides \pm 16 bundles. The style of $A$. arvensis is solid, having a loose transmission tissue without any vascular trace. The styles of $C$. nepalensis and S. gesneroides are hollow, supplied by four traces.

5. Species with four basal bundles: one of the commisural ventral bundles producing a septal branch

Pedicularis furfuracea (Rhinantheae) has two dorsal and two commisural ventral bundles and a single septal trace at base. Lateral traces are absent. Dorsal traces branch (Fig. 22) at a higher level. The middle part of the ovary wall contains $26-30$ bundles. Each of the commisural ventral bundles divides into two ventral traces within a short distance. The hollow style is supplied by two dorsal traces.

\section{Epidermis and trichomes}

The epidermis of the pedicel possesses thick cuticle in Verbascum virgatum, Angelonia grandiflora, Torenia fournieri, Lindernia crustacea, Scoparia dulcis, Veronica himalensis, Alectra arvensis, Striga gesneroides and Pedicularis furfuracea.

Attention of all workers on floral anatomy of Scrophulariaceae has naturally been drawn by the strikingly diverse nature of trichomes. The trichomes encountered may be classified into the following types (Fig. 25):

A - A group of basal cells, two rows of cells (2-4 in each row) forming a supporting stalk and a bunch of elongated terminal glandular cells.

B - A small basal cell, two supporting cells (lower long, the upper subterminal small) and elongated terminal glandular cells (as reported by S c h r o c k and P a ls e r, 1967, in Collinsia). 


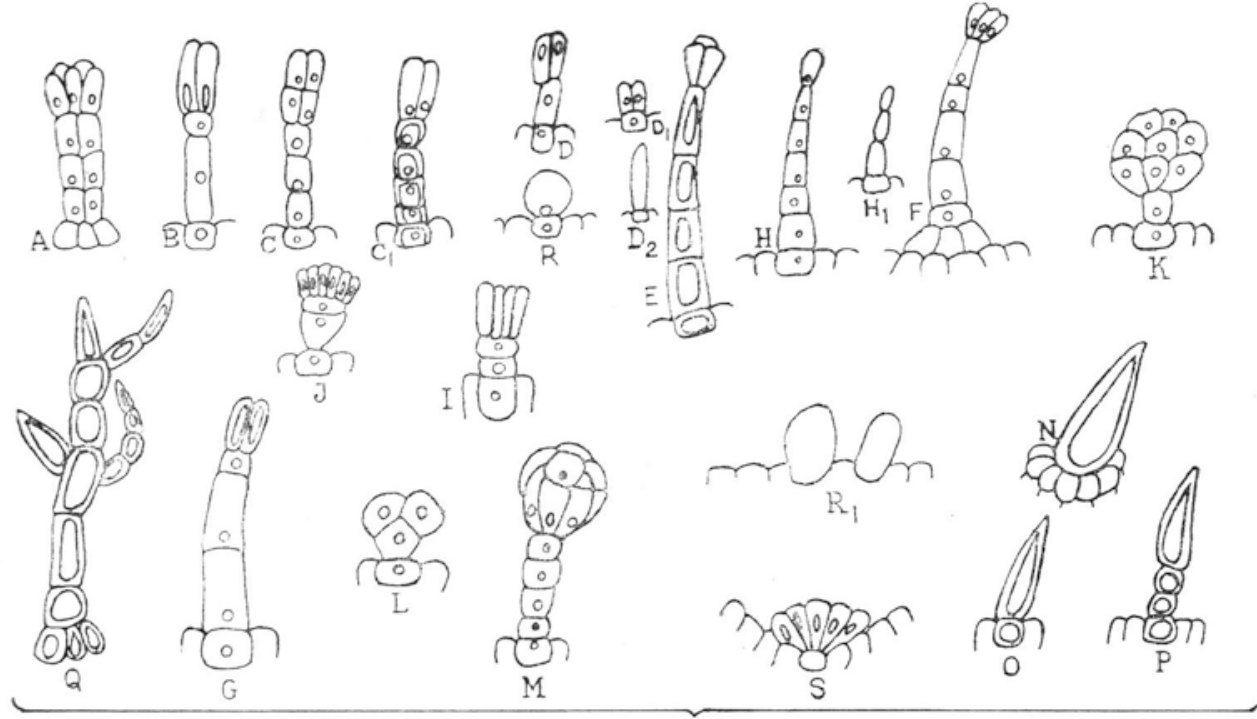

(25)

Fig. 25. Trichome types of flowers of Scrophulariaceae

C - A small basal cell, $3-5$ cells (more or less equal) forming a supporting stalk and four elongated glandular cells arranged in two tyers at the apex.

$\mathrm{C}_{1}$ - Same as $\mathrm{C}$, but two glandular elongated cells at the tip, instead of four.

D - A small basal cell, one elongated supporting cell and two terminal glandular cells.

E - A small thick-walled basal cell, a row of thick-walled cells forming a stalk and three to four terminal glandular cells, more or less obovate.

F - A group of basal cells, a small sub-basal cell in the stalk base, a row of $3-5$ cells in the supporting stalk, and three to four elongated glandular terminal cells.

G - A basal cell, a supporting stalk of three cells (the lowest and the middle long and equal, the uppermost or subterminal very small) and two elongated glandular cells gradually poducing thick walls.

$\mathrm{H}-\mathrm{A}$ basal cell, a gradually narrowing supporting stalk of $4-6$ cells, and a single terminal glandular cell.

I - A large basal cell, a short stalk of two flattened small cells and a bunch of about four elongated terminal glandular cells.

$\mathrm{J}$ - Similar to I, but the lower stalk cell narrow towards base, and the bunch of terminal cells larger (having about 6 elongated glandular cells). 
$\mathrm{K}$ - A basal cell, a single short supporting cell, and a dome of glandular cells (8-10).

L - A basal cell, and about three glandular cells forming a triangular structure, one of the glandular cells supporting it.

M - A basal cell, a stalk of $4-5$ cells, and a glandular dome of $10-$ 12 cells.

$\mathrm{N}$ - A group of basal cells and a thick walled pointed large cell.

$\mathrm{O}$ - A single thick-walled basal cell and a thick -walled pointed large cell,

P - A single thick-walled basal cell, a stalk of $2-7$ thick-walled celis and a thick-walled pointed large terminal cell.

Q - A dendroid type of trichome having all thick-walled cells and pointed terminal cells.

$\mathrm{R}$ - A basal cell and a globular cell.

$R_{1}$ - A group of globular cells (formed by transformation of some of the epidermal cells) partly embedded in the epidermal cells.

$\mathrm{S}$ - A basal cell and a thick rosette of elongated glandular cells directly on the basal cell.

Excepting Linaria bipartita, all species of Scrophulariaceae studied have different degrees of pubescens on floral organs. The pedicel possesses 2 -3-celled, $\mathrm{N}$ or $\mathrm{H}$ type of trichome in Verbascum virgatum, Calceolaria mexicana, Angelonia grandiflora, thin-walled 5-7 celled $\mathrm{P}, \mathrm{H}$ and $\mathrm{E}$ in Antirrhinum majus, densely pubescent with $\mathrm{O}, \mathrm{P}$ and $\mathrm{Q}$ types in Wightia speciosissima, D and $J$ types in Sutera glandulosa, I in Mazus japonicus, $\mathrm{P}$ in Lindenbergia indica, $\mathrm{R}_{1}$ in Torenia vagans, $\mathrm{F}$ and $\mathrm{S}$ in Lindernia multiflora, B and C in Veronica himalensis, non-glandular multicellular in Digitalis purpurea, $\mathrm{R}_{1}$ and $\mathrm{D}$ in Alectra arvensis, $\mathrm{N}$ and $\mathrm{E}$ in Centranthera nepalensis, $\mathrm{R}$ in Striga gesneroides. Hairs are absent in the pedicel of Russelia equisetiformis, Linaria bipartita, Brama monnieri, Pagesia dianthera, Torenia fournieri, Lindernia crustacea, Pedicularis furfuraecea, (very rare in L. ciliata, Scoparia dulcis).

Calyx contains $\mathrm{N}$ and $\mathrm{H}$ types on the abaxial surface of $V$. virgatum, $\mathrm{B}, \mathrm{C}$ and $\mathrm{A}$ on the adaxial surface of $A$. grandifiora, $\mathrm{H}$ on the abaxial surface of $C$. mexicana, $\mathrm{F}$ and $\mathrm{R}_{1}$ common on the abaxial surface and $\mathrm{K}$ on the adaxial surface of $A$. majus, $\mathrm{D}$ and $\mathrm{D}_{1}$ on the adaxial surface (near mid-vein) of $R$. equisetiformis, $\mathrm{O}, \mathrm{P}$ and $\mathrm{Q}$ densely distributed on abaxial surface of $W$. speciosissima, D and $J$ on the margin of Sutera glandulosa, I on the abaxial surface of M.rugosus, P and G on the abaxial surface of Lindenbergia indica, $\mathrm{S}$ and $\mathrm{R}$ on the outer surface of Pagesia dianthera, $\mathrm{R}_{1}$ on the abaxial surface of $T$. vagans, $\mathrm{L}$ on both the surfaces $L$. crustacea, $\mathrm{S}$ on the adaxial surface of $L$. ciliata, $\mathrm{F}$ and $\mathrm{S}$ on the inner surface of L. multiflora, B and C on both the surfaces of $V$. himalensis, $\mathrm{H}_{1}$ on abaxial surface of $D$. purpurea, $\mathrm{O}$ and $\mathrm{P}$ on both the surfaces of Alectra arvensis, $\mathrm{P}, \mathrm{N}$ and $\mathrm{E}$ on the abaxial surface of $C$. nepalensis, 
$R_{1}$ and $H$ on the abaxial surface of Striga gesneroides, $R_{1}$ on the abaxial surface of $P$. furfuracea. Trichomes are very rare in Brama monnieri, Scoparia dulcis, and absent in Linaria bipartita and T. fournieri.

On corolla, B type occurs in C. mexicana generally on the folded regions of pouches, mainly on the abaxial surface, $F$ type on the outer surface of A. majus, $\mathrm{H}$ on the adaxial surface of $R$. equisetiformis, I and $\mathrm{R}$ on the abaxial surface of $M$. japonicus, $\mathrm{H}_{2}$ (unicellular) on the adaxial surface of Pagesia dianthera and on the abaxial surface of T. vagans, $L$ on the adaxial surface of Lindernia crustacea, $\mathrm{M}$ on the abaxial surface of $L$. ciliata, a few $\mathrm{F}$ and $\mathrm{S}$ on the adaxial surface of $L$. multiflora, $\mathrm{H}_{1}$ on the adaxial surface of D. purpurea, B and C on both the surfaces of Veronica himalensis, $\mathrm{O}$ and $\mathrm{P}$ on both the surfaces of the corolla of Alectra arvensis, $\mathrm{E}$ on the abaxial surface of $C$. nepalensis, $\mathrm{H}$ on the outer surface of Striga gesneroides and $R_{1}$ on the abaxial surface of $P$. furfuracea. Trichomose on corolla surface is almost absent in V. virgatum, A. grandiflora, Linaria sp., W. speciosissima, Su. glandulosa, Lindenbergia indica, Brama monnieri and T. fournieri.

On stamens, $\mathrm{N}$ occurs on the connective of Verbascum virgatum, long pointed multicellular hairs on the adaxial surface of Angelonia grandiflora, $\mathrm{H}$ on the abaxial surface of filaments of C. mexicana. Trichomes are almost absent on the stamen of Linaria bipartita, Antirrhinum majus, Russelia equisetiformis, W. speciosissima, Sutera glandulosa, Mazus japonicus. Lindenbergia, indica, Brama monnieri, Pagesia dianthera, Torenia species, Lindernia species, Scoparia dulcis, Veronica himalensis. D. purpurea, Alectra arvensis, Striga gesneroides, Centranthera nepalensis, P. furfuracea.

On carpels, $\mathrm{C}_{1}$ occurs on the ovary wall of Angelonia grandiflora, $\mathrm{R}_{1}$ on the ovary wall of $C$. mexicana, $R_{1}$ on the ovary wall of $T$. fournieri, $\mathrm{H}_{1}$ on the ovary wall of $D$. purpurea, $\mathrm{D}$ on ovary wall of Alectra arvensis. Trichomes are absent in V. virgatum, Linaria bipartita, A. majus, R. equisetiformis, W. speciosissima, Sutera glandulosa, Mazus japonicus, Lindenbergia indica, Brama monnieri, Pagesia dianthera, T. vagans, Lindernia species, Scoparia dulcis, Veronica himalensis, Centranthera nepalensis, Striga gesneroides, P. furfuracea.

\section{DISCUSSION}

Taxonomy of the species:

The sub-family Pseudosolaneae of $\mathrm{B}$ e $\mathrm{n}$ th a $\mathrm{m}$ and $\mathrm{H}$ oo k e r (including tribes Leucophylleae, Aptosimeae and Verbasceae) and of W t t$\mathrm{s}$ te in (including Verbasceae and Aptosimeae) was thought to be distinct, primitive and related to Solanaceae, for their five stamens, absence of zygomorphy, etc. But Pennell (1935) concludes that these characters 
in Scrophularianceae are all derived, and unrelated to Solanaceae. Hence P e n e ll drops the "super group" Pseudosolaneae, and places the species under Antirrhinoideae. In the present study, all five staminal traces are noticed in most of the species of the family. Clear zygomorphy is absent in Antirrhinideae also.

In formulating the new classification, $\mathrm{P}$ e $\mathrm{n} \mathrm{n}$ e 11 makes the first cleavage into Antirrhinoideae and Rhinanthoideae, distinguished by the relative positions of corolla lobes, the former having external posterior (upper) lobes overlapping in the bud and the latter having external anterior (lower) lobes overlapping in the bud. The character of external anterior lobes, according to Pennell, tends to be associated with much specialization of flower and specialized habits of root-parasitism. Therefore, of these two groups, Rhinanthoideae is more evolved. For this redefination of the subfamilies, a few genera of original Rhinanthoideae (e.g. Digitaleae) have been transferred to Pennell's Antirrhinoideae. Similarly some genera of Cheloneae (Antirrhinoideae) have been transferred to Buchnereae (Rhinanthoideae). The study of vasculature does not provide any clear basis of distinction of the subfamilies.

Floral vasculature aiding taxonomy:

If one wants to classify species purely on the basis of vascularization pattern, number of stamen traces will appear to him as a good basis. Verbascum virgatum can be distinguished by five stamen traces supplying five fertile anthers. The common type, four fertile and one vestigial traces, is found in all other species studied here, excepting Scoparia dulcis, Veronica himalensis and Calceolaria mexicana, having four stamen traces. within these three again, Scoparia dulcis has four fertile traces, while the other two have two fertile and two vestigal. Such a classification is no doubt artificial, and is incompatible with the views of all taxonomists. According to Carlquist (1969), presence of vascular bundles should be interpreted as functional structures related to actual physiological activity, not merely as vestiges that do not function but have not yet been lost.

Presence of cords formed by fusion of sepal midrib traces and stamen traces may also appear as a clear character for classification. But this character also is absent in genera of both the subfamilies, e.g. Verbascum, Angelonia, Russelia, Wightia, Brama, Pagesia and Scoparia of Antirrhinoideae (of P e n n 11); and Veronica, Digitalis, Centranthera, Striga and Pedicularis (of Pennell). Grateoleae, a primitive tribe of Pennell's Antirrhinoideae, thus, is characterized by both presence and absence of the cord. In the Rhinanthoideae, all tribes, primitive or advanced, have some genera without this cord. This suggests a polyphyletic evolution in 
the family, this cord appearing at the ends of the different evolutionary branches and sub-branches.

Similar to adhesion, cohesion of traces, e.g. sepal-lateral commisural trace, is common in this family. This commisural trace is absent in Russelia equisetiformis, Sutera glandulosa and Digitalis purpurea.

Although, for broad classification of the family, clear distinction in vasculature of flowers is absent, characters supporting Pennell's classification are available. For example the position of Scoparia dulcis appears more natural near Brama and Pagesia of Antirrhinoideae (as in Pennell's), than with Digitalis of Rhinanthoideae (as in other systems). The reasons are: Scoparia, Brama and Pagesia are characterized by (1) absence of sepal-midrib + stamen trace cord (also in Digitalis), (2) short petal-midrib + sepal-lateral cord (also in Lindernia), (3) presence of sepal-lateral commisural strands (absent in Digitalis), (4) distinct and parallel anther cells, (5) turgid long capsules, (6) external upper corolla lobe, (7) free sepals. Digitalis can be distinguished from Scoparia by (1) absence of sepal-lateral commisural strands, (2) longer petal-midrib + sepal-lateral cords, (3) external lower corolla lobes, (4) divaricate anther cells, (5) long terminal racemes and ovate capsules having septicidal dehiscence. The vascular patterns of carpels of Scoparia, Digitalis, Torenia, genera of Gratiolae and Veronica are of the same plan. But Digitalis differs by the presence of 20-24 bundles on the ovary wall, in contrast to eight in others. The position of the vestigial or lost stamen traces is posterior in Digitalis, Veronica, Scoparia, Torenia, Brama, Pagesia and Mazus, while it is anterior in Lindenbergia and Lindernia species. Therefore, this trace provides no clue to classification.

The separation of Digitalis and Veronica under Digitaleae and Veroniceae finds justification in (1) the presence of two fertile and two vestigial stamen traces without adhesion in Veronica, and four fertile and one vestigial stamen traces without adhesion in Digitalis, (2) ovary wall having eight bundles in Veronica himalensis and 20-24 in Digitalis purpurea; (3) a fusion of two traces in the upper part of style of Veronica, a feature absent in Digitalis; (4) corolla being declined in Digitalis, rotate in Veronica; (5) stamens being two posteriolateral, with exerted anthers in Veronica, and four included in Digitalis; (6) anther lobes being parallel and confluent in Veronica, divergent in Digitalis, (7) stigma being subcapitate in Veronica and distinct in Digitalis.

Placement of Sutera (Manuleae of older systems) under Grateoleae by Pennell seems more natural. Sutera glandulosa has carpellary traces very similar to that of Brama monnieri, having eight basal traces, two entering into the septum and discontinuing in the upper ovary. The stamen traces of $S$. glandulosa corresponds perfectly with that of Linaria, Mazus, Lindernia, Brama, Pagesia, Torenia and Lindenbergia of Grateoleae. 
Though Pennell has placed Calceolaria under Cheloneae (near Russelia and Wightia), on the basis of external morphological characters, vascular supplies of flowers differ markedly; (1) Calceolaria mexicana has vestigial traces and two traces for fertile stamens, fused with traces of perianth and carpels, while the species of Cheloneae have one sterile and four fertile traces distinct from outer and inner whorls. (2) The eignt carpel traces of $C$. mexicana at first arise fused with the staminal and perianth traces, while in Cheloneae, the lateral bundles and ventral fusion bundles arise free from adhesion. (3) In Calceolaria the septum is primarily supplied by a single trace which divides into two, while in the species of Cheloneae, two prominent traces enter the septum, each of which may further divide (as in Russelia). (4) Number of traces for sepals and petals are ten and five respectively in Cheloneae, while it is eight and four in Calceolaria.

Evolutionary status of tribes and subfamilies

From the evolutionary point of view, cohesion, adhesion, reduction or elimination of traces are generally accepted as advanced characters (Eames, 1931, 1953; Manning, 1940; Puri, 1951; T e pfer, 1953 and many other authors). Of course, C a r lquist (1969) has pointed out that the directions of evolution does not follow the same plan always. Evolution may accompany freedom and elaboration of traces as well. Correlation of external and anatomical characters may be helpful to get definite clues on evolution.

Pennell's conclusions on phylogeny show that (1) Rhinanthoideae are advanced over Antirrhinoideae for specialized habits of root parasitism. (2) Psedosolaneae of previous taxonomists (Verbasceae and Leucophylleae of Pennell) are not primitive, but derived and more evolved than Gratioleae of Antirrhinoideae. (3) Gratioleae, for their simple inflorescence, opposite leaves, many seeded capsule and reticulate seed coat seem to be most primitive. (4) Antirrhineae (tribe) are among the most highly evolved tribe of Scrophulariaceae for elaborate zygomorphy of corolla, attended by pouches or spurs for the nectar, the remarkably modified capsule dehiscence and scattered phyllotaxy. (5) Digitaleae are primitive and Euphrasieae are most advanced among the tribes of Rhinanthoideae. This sequence is found in all other classifications also. (6) Cheloneae are more advanced than Verbasceae and Gratioleae.

Following paragraphs representing combinations of characters in groups mentioned above will help in understanding their degree of specialization.

In Grateoleae sepal-stamen cord, sepal-petal cord, sepal-lateral commisural traces are common (Table 1). One stamen trace is either 


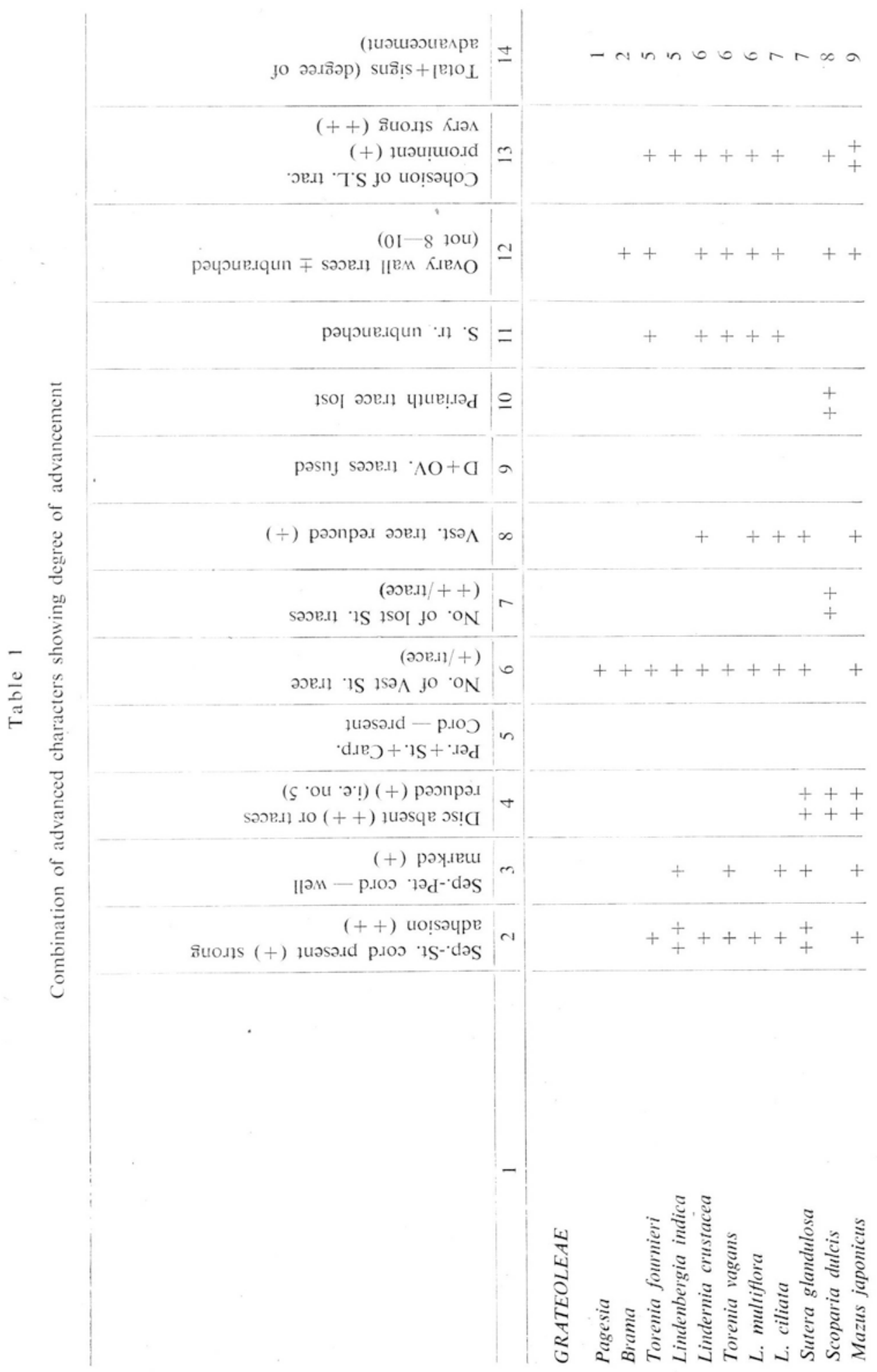




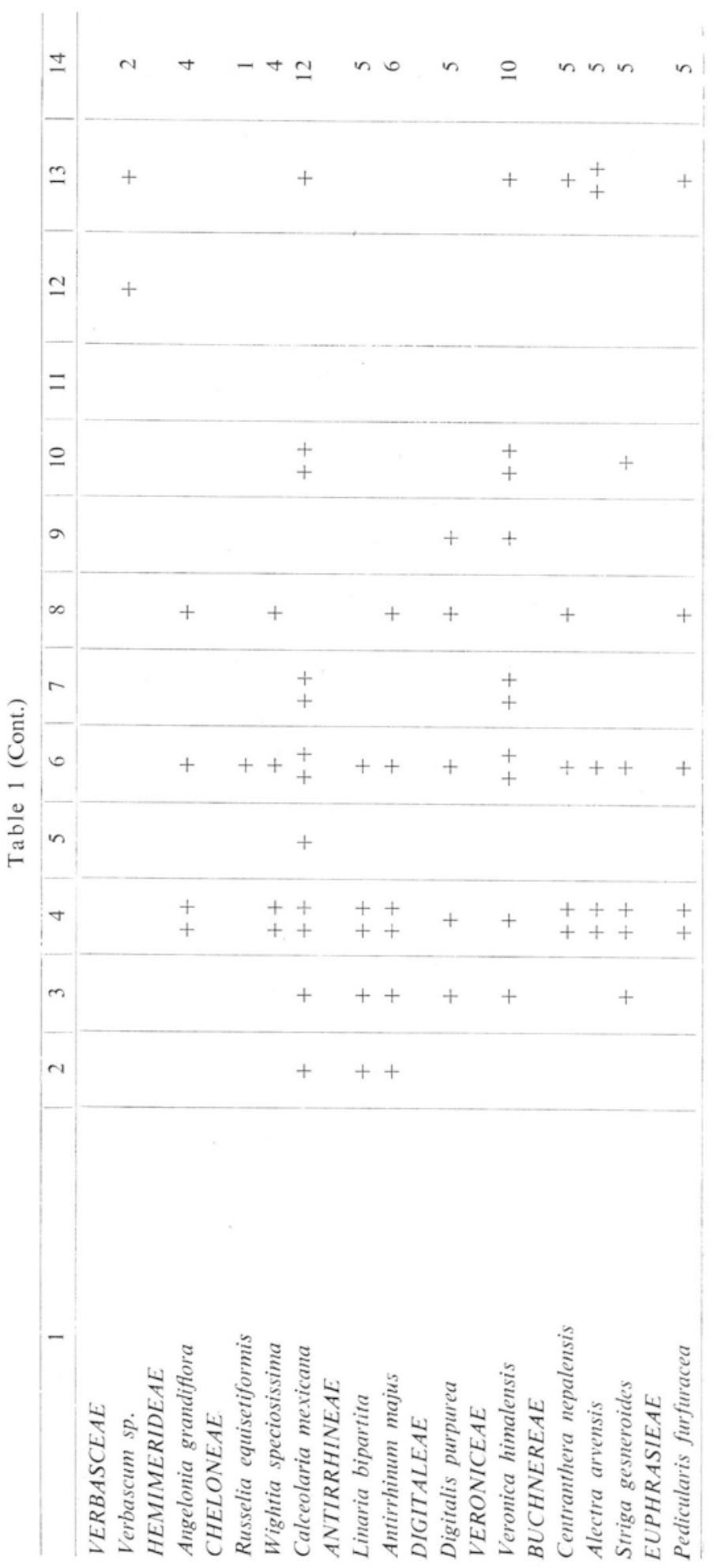


vestigial or absent. Vestigial traces show gradation of reduction (Figs. 23 \& 24). Disc is generally present, absent in a few species. Perianth traces are branched or unbranched (in sepals). Ovary traces are generally eight, two ventral (commisural), two dorsal and four lateral. Highly branched ovary wall traces are found in Pagesia and Sutera. For the presence of only a single advanced character (one vestigial stamen trace), Pagesia dianthera seems to be the most primitive species. Brama monnieri is slightly advanced for having two such characters (single vestigial stamen trace and unbranched carpel traces). Mazus japonicus appears as the most advanced species for the highest number of advanced characters. Table 1 shows that the species of Grateoleae have a range of one to nine such advanced characters.

Verbascum virgatum is distinct from Grateoleae for the absence of all cords, vestigial or aborting stamen trace, etc. Only two advanced characters (reduced branching of carpel traces and short sepal lateral commisural traces) are present. Angelonia grandiflora (not mentioned by Pennel1), placed under Hemimerideae (Antirrhinoideae) of Bent$\mathrm{ham}$ and Hooker, may be characterized by absence of disc and presence of a highly reduced vestigial stamen trace. Species of Cheloneae show a range of one to twelve plus $(+)$ signs, which may be regarded as indications of degrees of advancement.

The two species of Antirrhineae have fairly large number of advanced characters, but lack in the cohesion of sepal lateral traces. Similarly, another advanced species, Digitalis purpurea, may be distinguished by two primitive features, absence of sepal-stamen cords and sepal-lateral commisural strands. Veronica himalensis, one of the most advanced species, is without adhesion of sepal and stamen traces. Actually all species of Rhinanthoideae are without cohesion of traces for sepals and stamens.

Figure 26 shows the range of the gradiation of suposed advanced characters. This figure shows that the plan of advancement, on the basis of those characters, does not oppose the conclusions of Pennell. Grateoleae appears to be the most primitive tribe, Antirrhineae stands as one of the fairly advanced groups, Rhinanthoideae are more advanced than Antirrhinoideae and Verbascum is not so primitive as is found in the older classifications. Investigation with more species will certainly show a better correlation.

\section{Trends of evolution of floral vasculature}

Measurements of unbranched portions of midribs of petals and sepals, petal-sepal cords, sepal-lateral commisural strands, sepal-stamen cords, vestigial stamen traces, height of disc traces in relation to the total height of the floral axis (Table 2). The table also represent gradiations of 


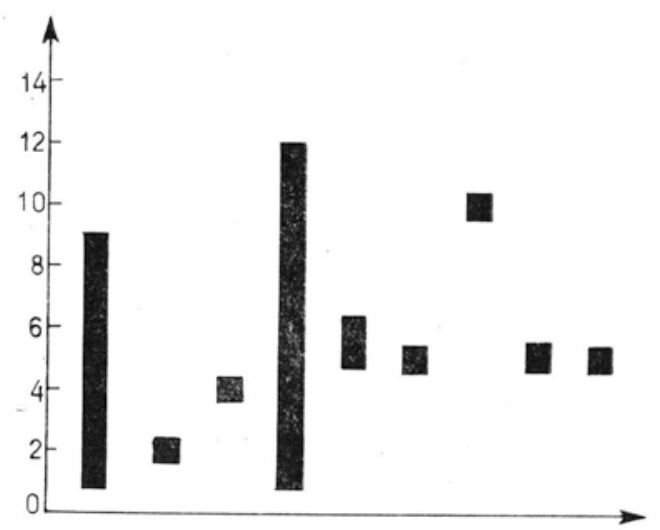

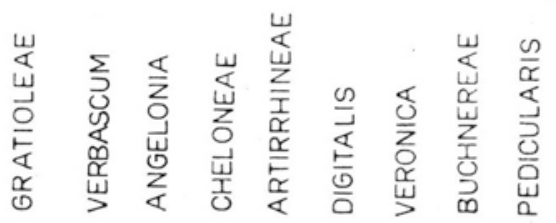

Fig. 26. Histogram range of specialization grades (as shown in Table 1) of the tribes of Scrophulariaceae

advancement based on arbitrary equal divisions of the measurements. Mean of these seven gradations has been calculated (column 10 of Table 2).

For further analysis it will be convenient to concentrate on Grateoleae, of which the largest number of species has been studied. Fig. 27 shows that the mean values of advanced characters (Table 2, column 10; shown in A of the Fig.) fit perfectly with the order of arrangement of species of Grateoleae in Table 1 on the basis of the number of + signs. But the characters when considered individually (represented as A - mean of total advanced characters, B - height of petal + sepal main bundles, C - sepal lateral commisural trace, D - sepal lateral petal cord, E vestigial stamen trace, F - sepal stamen cord, G - height of disc), correlation is imperfect. Of course, most of the characters of Brama monnieri and Pagesia dianthera appear as comparatively less advanced while those of Mazus, Scoparia, Sutera and Lindernia are generally most evolved. This suggests that the general trends of evolution are of reduction and fusion of traces, though certain species may lag in some of the trends. Thus the family is an array of different trends of evolution involving both reduction and fusion of traces. For example, Torenia fournieri, unreduced in most of the characters, has remarkably reduced perianth trace branches. Cohesion of sepals is very short or absent in Scoparia dulcis and Sutera glandulosa, the two very highly reduced advanced species. Absence of adhesion of traces for sepals and stamens in Scoparia is also a contrasting character among all other trends of reduction and fusion. 


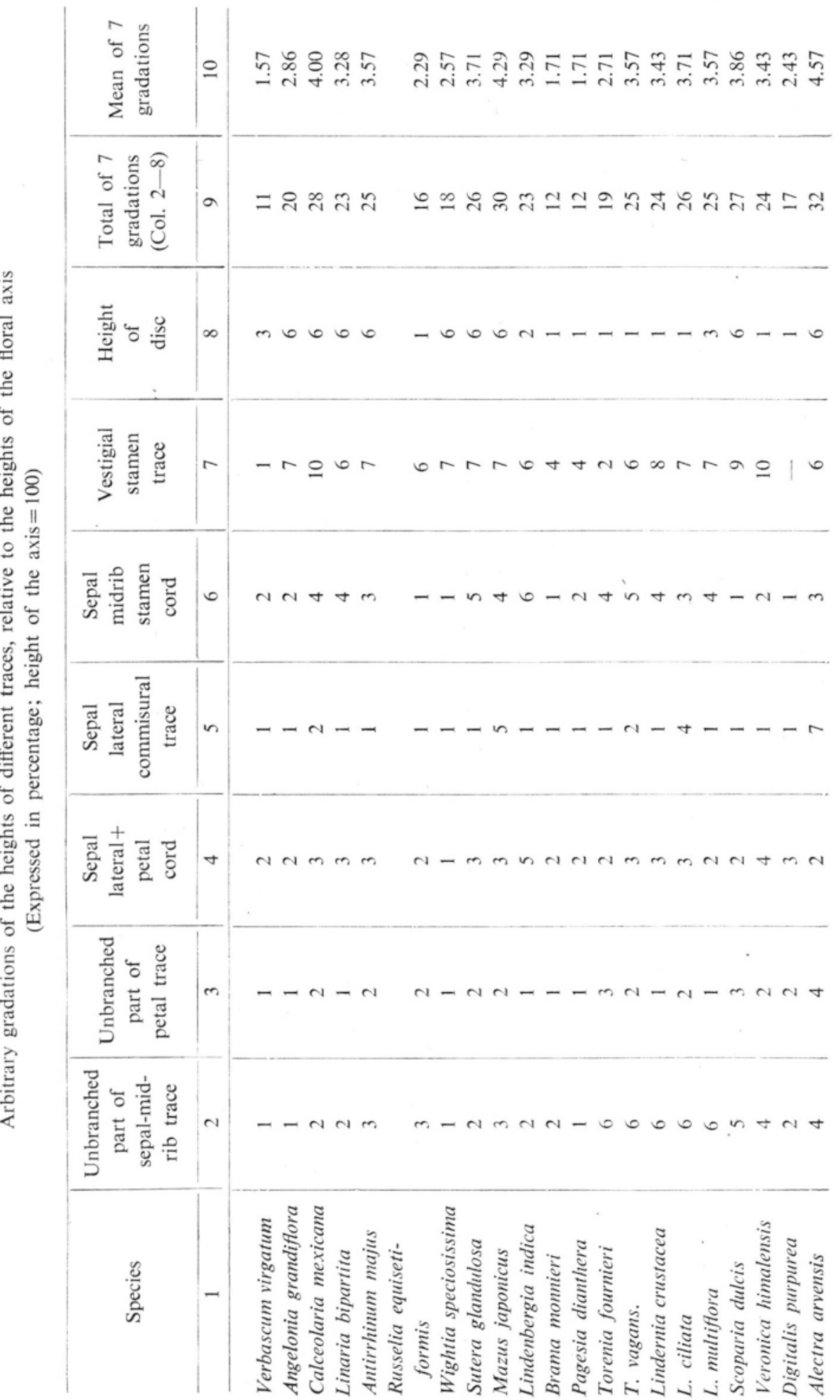




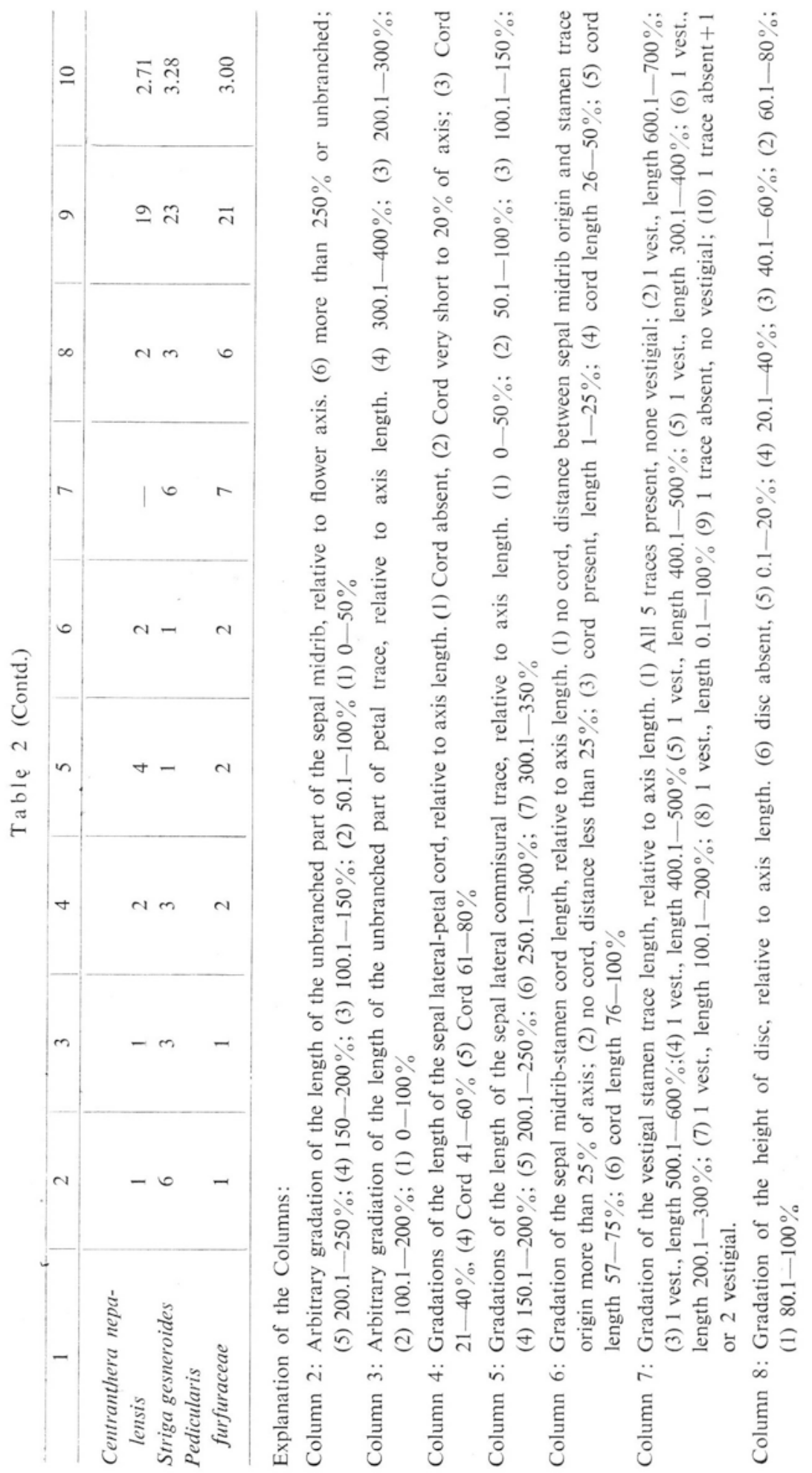




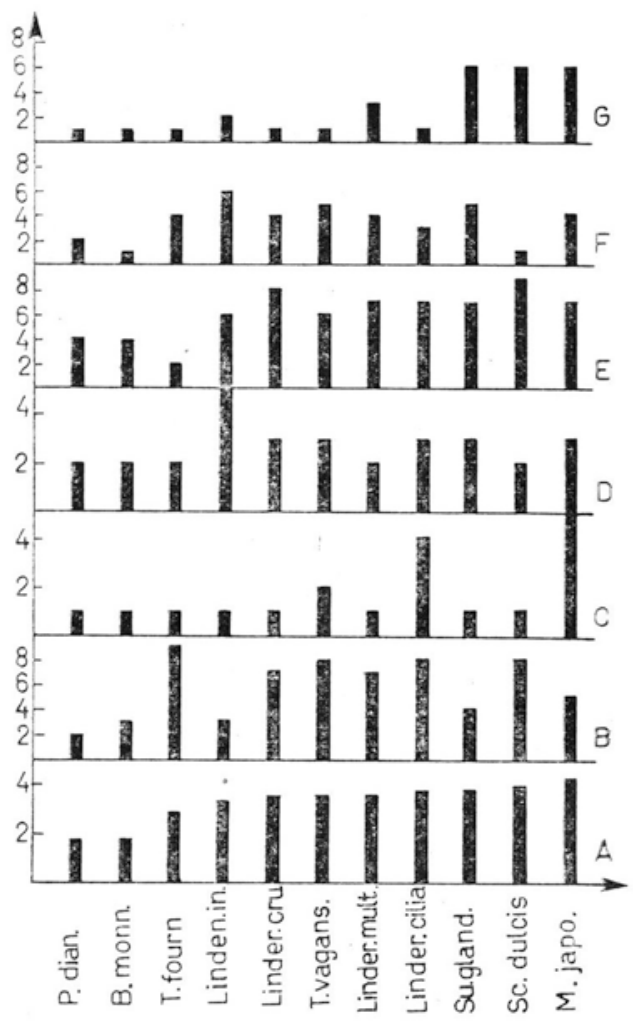

Fig. 27. Grateoleae - histogram showing comparison of degrees of specialization of characters. A - column 10 of Table 2, mean value of all gradations of characters; $\mathrm{B}$ - total of gradations of the length of unbranched portions of sepal- and petalmain-traces, i.e. total of columns 2 and 3 of Table 2; C - length gradation of sepal lateral commisural traces, column 5 of table 2; D - length gradation of sepal lateral petal cord (column 4 of table 2); E - length gradation of vestigial stamen traces, column 4 of table 2; F - length gradation of sepal stamen cord, column 6 of table 2;

$\mathrm{G}$ - height gradation of disc traces, column 8 of table 2

On the whole, Grateoleae are a primitive group, as described by Pennell. Among the species of Grateoleae, the fundamental common trend is the reduction or loss of a stamen trace. There are three major trends, (1) the reduction of all traces, but no cohesion or adhesion (as in Scoparia dulcis), (2) fusion of traces, with less reduction (culminated in Sutera glandulosa), (3) both fusion and reduction of traces (culminated in Lindernia species and Mazus japonicus). Angelonia grandiflora shows reduction of stamen and disc traces only, but without a tendency of fusion of traces. Verbascum virgatum represents slight fusion (only the sepal laterals) and slight reduction of traces. In Cheloneae the fundamental strong trend is the reduction of traces. The fusion of bundles probably gradually appear in the most evolved species like Calceolaria mexicana. The two species of Antirrhinae are characterized by reduction of disc 
mainly and by adhesion of perianth and stamen traces. No cohesion and no reduction of other traces is noticed. All species of Rhinanthoideae lack adhesion of sepal and stamen traces and the reduction, particularly of stamen and disc traces (not fusion) is the main trend.

Trichomes of flowers and demarcation of species

The distribution of trichome types does not show any clear relation. Even in the same genus (like Torenia), variation of types of trichomes and patterns of distribution is noticed. Still, a glance on the description of types and distribution of them shows that the tribe Grateoleae has a preponderance of glandular trichomes. Cheloneae possesses some glandular types with long non-glandular supporters and many purely non-glandular types. Buchnereae and Pedicularis shows preponderance of non-glandular thick-walled trichomes.

This fact suggests that the trichomes show a broad trend of evolution from purely glandular types (like $\mathrm{S}, \mathrm{D}_{1}, \mathrm{R}$ or $\mathrm{L}$ ) to glandular types with short non-glandular stalk (D, I and J). All these types are common in Grateoleae. $\mathrm{K}$ and $\mathrm{M}$ with multicellular globular glandular heads probably represent a different line. The next change is probably in further proliferation of the non-glandular stalk (as in A, B, C, C $1, E, F, H$ and G). These types are found in Angelonia and Antirrhineae. The next step covers dendroid or simple multicellular or unicellular thick-walled non-glandular trichomes (e.g. O, P, Q and N), which are common in Buchnereae and Cheloneae. Further critical study of trichomes, including their developmental anatomy in different organs, vegetative and reproductive, may reveal definite trends of evolution.

\section{SUMMARY}

Investigation into some important aspects of floral anatomy of 24 species of Scrophulariaceae reveals that although clear anatomical bases of distinguishing flowers of different taxa are absent, reasons supporting the classification of $\mathrm{Pennell}$ are available. For example, position of Scoparia dulcis in Grateoleae appears more natural than in Digitaleae. Transposition of Sutera (Manuleae of $\mathrm{Bentham}$ and $\mathrm{Hooker}$ under Grateoleae is supported by the nature of the traces of stamens and carpels. Separation of Digitalis and Veronica and their placement under two tribes by Pennell finds justification in their distinct patterns of staminal and carpellary bundles. Floral vasculature of Calceolaria mexicana is distinct from that of Wightia speciosissima and Russelia equisetiformis of Cheloneae. Placement of Calceolaria mexicana under Cheloneae by $\mathrm{P}$ en $\mathrm{n}$ ll seems therefore unnatural. 
Plan of advancement of floral structures supports fairly the classification of Pennell. Grateoleae appears as the most primitive tribe. Antirrhineae are fairly advanced. Rhinanthoideae are more evolved than Antirrhinoideae. Verbascum is not so primitive as is found in older classifications.

Particular types of trichomes are preponderant in flowers of particular tribes. Their distribution patterns seem to be species specific. Correlation of trichome types with the evolution of taxa within the family suggests a gradual change from purely glandular to non-glandular dendroid or unbranched or unicellular thick-walled types.

Acknowledgement

Authors are grateful to the Officers of Botanical Survey of India, Western and Eastern Circles and Professor A. K. Sharma of Calcutta University for kindly supplying many herbarium samples for the work.

\section{REFERENCES}

Arber, Agen S., 1932. Studies in flower structure I. On a peloria of Digitalis purpurea L. Ann. Bot., 46: 929-939.

B a n croft. H., 1935. A review of researches concerning floral morphology. Bot. Rev. 1: 77-99.

Bentham G. and Hooker J. D., 1873. Genera Plantarum. L. Reeve Co., London, 2: 913-980.

Carlquist S., 1969. Toward acceptable evolutionary interpretations of floral anatomy. Phytomorphology 19 (4): 332-362.

E a mes A. J., 1931. The vascular anatomy of the flower with refutation of the theory of carpel polymorphism. Amer. Hort. Bot. 18: 147-188.

E a mes A. J., 1953. 'Floral anatomy as an aid in generic limitation. Chronica Botanica 14: 126-132.

E a m e s A. J., 1961. Morphology of Angiosperms. McGraw-Hill, New York.

Fernald M. L., 1950. Gray's manual of botany. 8th ed. American Book Co., New York.

F is her M. J., 1928. The morphology and anatomy of the Salicaceae. Amer. Jour. Bot., 15: 307-26.

Hartl D., 1956. Morphologische Studien am Pistill der Scrophulariaceen. Österreichische Bot. Z. 103: 185-242.

Henslow G., 1891. On the vascular systems of floral organs and their importance in the interpretation of the morphology of flowers. J. Linnean Soc. Bot. 28: $151-197$.

J o h a n sen D. A., 1940. Plant Microtechnique. Mc.Graw-Hill Book Co. Inc., New York and London: 42.

J us t T., 1952. Origine et evolution de la fleur. Annie. Biol. 28: 135-48.

Krishna Iyengar C. V., 1937. Development of embryo-sac endosperm haustoria in some members of Scrophularineae. I. An account of Sopubia delphinifolia. G. Dm. and Alonsoa sp. J. Indian Bot. Soc. 16: 99-109.

Krishna Iyengar C. V., 1940a. Development of embryo-sac and endosperm haustoria in some members of Scrophularineae III. Limnophila heterophylla Benth. and Stemodia viscosa Roxb., Ibid. 18: 35-42. 
K r ishna I yengar C. V., 1940b. Structure and development of seed in Sopubia trifida Ham., Ibid. 19: 251-261.

Manning W. E., 1940. The morphology of the flowers of the Juglandaceae II. The pistillate flowers and fruits. Amer. Jour. Bot. 27: 838-852.

M a the w s J. R., 1941. Floral morphology and its bearing on the classifications of angiosperms. Trans. Bot. Soc. Edin. 23: 69-82.

Pennell F. W., 1935. The Scrophulariaceae of Eastern Temperate North America. Acad. Nat. Sci. Philadelphia, Monograph No. 1. Wickersham Printing Co., Lancaster, U.S.A.

P u r i V., 1951. The role of floral anatomy in the solution of morphological problems. Bot. Rev. 17: 471-553.

R a ghavan T. S., and Srinivasan V. K., 1941. Morphological and cytological studies in the Scrophulariaceae. IV. The Development of the embryo-sac endosperm in Scoparia dulcis Linn. Indian Acad. Sci. Proc. B. 13: 24--32.

$\mathrm{R}$ a i z a d a M. B., 1958. Name changes of common Indian plants. Ind. For. 84: $467-538$.

R a o V. S., 1953. The floral anatomy of some bicarpellate. 1. Acanthaceae. Jour. Univ. Bombay Col. 21: 1-34.

Safeeulia K. M. and Govinda H. C., 1950. Development of the female gametophyte and endosperm in Bacopa hamiltonia. Lloydia 13: 179-182.

S a unders Edith R., 1934. A study of Veronica from the view point of certain floral characters. J. Linnean Soc. Bot. 49: 453-493.

Schrock G. F. and Palser B. F., 1967. Floral development, anatomy and embryology of Collinsia heterophylla with some notes on other species of Collinsia and on Tonella tenella. Bot. Gaz. 128 (2): 83-104.

Srinivasan A. R., 1946. Morphological and cytological studies in Scrophulariaceae. V. Striga euphrasioides Benth. Indian Acad. Sci. Proc. B. 24: 21-23.

Srinivasan V. K., 1940. Morphological and cytological studies in the Scrophulariaceae. II. Floral morphology and embryology of Angelonia grandiflora C. Morr. and related genera. J. Indian Bot. Soc., 19: 197-222.

Stern W. L. and Chambers K. L., 1960. The citation of wood specimens and herbarium vouchers in anatomical research. Taxon 9: 7-13.

Tepfer S. S., 1953. Floral anatomy and ontogeny in Aquilegia formosa var. truncata and Ranunculus repens. Univ. Calif. Publ. Bot. 25: 513-648.

Wettstein R. V. [in:] Engler A. and Prantl K., 1897. Die natürlichen Pflanzen familien. Verlag von Wilhelm Engelmann, Leipzig, 4: 39-107.

Authors' address:

Dr P. C. Datta and Arati Deb

35, Ballygunge Circular Road,

Calcutta-19; India 
Unerwienie $i$ owlosienie pospolitych indyjskich gatunków z rodziny

Scrophulariaceae

\section{Streszczenie}

Badania niektórych istotnych aspektów budowy kwiatów 24 gatunków Scrophulariaceae wykazały, że chociaż brak wyraźnych anatomicznych podstaw wyróżniających kwiaty różnych taksonów, to jednak przeprowadzone obserwacje anatomiczne popierają klasyfikację Pennella. Wydaje się na przykład, że umieszczenie Scoparia dulcis w Gratioleae jest bardziej naturalne niż w Digitaleae. Charakter śladów pręcikowych i owocolistkowych popiera przeniesienie gatunku Sutera (Manueleae, wg B enthama i Hookera) do Grateoleae. Oddzielnie Digitalis i Veronica i umieszczenie ich w odrębnych plemionach przez Pennella, znajduje uzasadnienie w odrębnych układach wiązek pręcikowych i owocolisktowych. Natomiast unerwienie kwiatowe Calceolaria mexicana różni się od unerwienia kwiatowego Wightia speciosissima i Russelia equisetiformis z Cheloneae, umiejscowienie przez P e n n e 11 a Calceolaria mexicana w Cheloneae jest więc nienaturalne.

Stopień ewolucyjnego zaawansowania struktur kwiatowych popiera silnie klasyfikację Pannella. Grateoleae wydają się być najprymitywniejszym plemieniem. Antirrhineae są ewolucyjnie zaawansowane, a bardziej od nich zaawansowane są Rhinanhoideae. Verbascum nie jest tak prymitywnym gatunkiem, jak to wynika z dawniejszych klasyfikacji.

W poszczególnych plemionach występują na kwiatach określone typy włosków. Układ ich rozmieszczenia jest gatunkowo specyficzny.

Korelacja typu włosków z ewolucją taksonów w obrębie rodziny sugeruje stopniowe przejście od czysto gruczołowatych do niegruczołowatych, dendroidalnych albo nierozgałęzionych lub do jednokomórkowych, grubościennych typów włosków. 